\title{
Thomas Wakley, Astley Cooper and the death of George IV
}

Roger Jones

J R Soc Med 2007;100:314-320

\section{INTRODUCTION}

King George IV of England died on 26 June 1830. His last illness and death were the subject of a series of astonishingly critical articles published in the Lancet, which castigated not only the quality of information contained in the bulletins from Windsor Castle about the Royal Illness, but also the quality of medical care that the King received. These articles were written by Thomas Wakley, the legendary founding editor of the Lancet, and were not only scathing about the King's medical attendants, but repeatedly demanded to know why Sir Astley Cooper, regarded by many as the leading clinician of his day, had not been called to the Court to minister to the King. Cooper had got to know the King socially after performing a minor operation on him several years before and had been widely applauded for his treatment of the Duke of York in 1827, who eventually succumbed to congestive cardiac failure. Wakley had smelt a medical rat at Court, and repeatedly referred to 'the conjuror' and 'the magician', a shadowy presence behind the throne who, for obscure reasons, was determined to keep Cooper away from the King's deathbed. Wakley was so exercised by Cooper's exclusion from the care of George IV that he demanded that the matter be debated in Parliament.

The epicentre of this drama, involving three extraordinarily colourful characters, is Guy's Hospital, London. Sir Astley Cooper was the senior surgeon at Guy's, Wakley trained there, and so did another individual who, as we shall see later, may have had more than a little to do with the exclusion of Cooper from the Court at Windsor.

\section{THOMAS WAKLEY}

Thomas Wakley was born the son of a country squire in Membury, Devon on 11 July 1795 (Figure 1). At the age of 15 he was apprenticed to an apothecary in Taunton and, excelling at his studies, moved to London at the age of 20 as a medical student at what had become known as the Borough Hospitals (St Thomas' and Guy's). With financial support from his future father-in-law, Mr Goodchild, a lead merchant of Tooley Street, London, he bought a practice in Argyle Street, near Oxford Circus. Only a few months after marrying the wealthy merchant's daughter, Wakley was

Wolfson Professor of General Practice, Dept of General Practice \& Primary Care, King's College London, 5 Lambeth Walk, London SE11 6SP, UK attacked in his hallway, apparently with murderous intent, and the house was burnt down around him. Wakley had been feeling out of sorts:

'having applied two leeches to my temples in consequence of dimness of sight and the leeches not readily taking I was kept up to the late period of after twelve o'clock.'

A stranger gained entry by spuriously claiming to be delivering a message, and while Wakley was fetching him the glass of cider the 'messenger' had demanded to slake his thirst, his accomplices rushed in, attacked Wakley with knives and clubs and set fire to his house. The bizarre, and scarcely-credible, explanation for this attack and the arson was that Wakley was suspected of having decapitated five corpses of criminals who had been sentenced to death for their part in what became known as the Cato Street Conspiracy, a plot to assassinate members of Lord Liverpool's cabinet. Unfortunately, because of the dexterity with which the decapitations were conducted-which aroused the anger of the watching mob - it was thought that they had been performed by a member of the medical profession. A newspaper article subsequently stated that the masked operator was a young surgeon of Argyle Street, although the origin of this information has never been established. It is likely that the surviving members of the

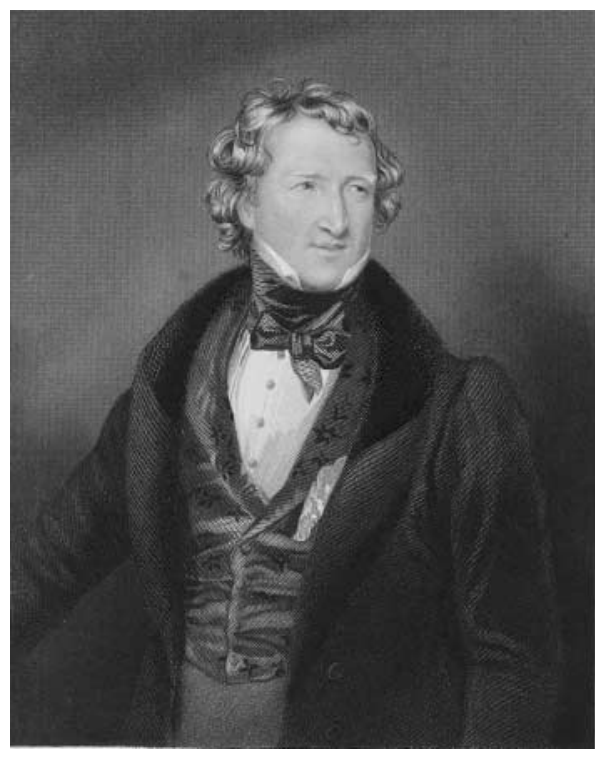

Figure 1 Thomas Wakley. 
Cato Street Conspiracy were bent on Wakley's destruction. ${ }^{1}$ Adding insult to injury, Wakley's insurers refused to pay for the damage, insinuating that Wakley had caused the fire himself, although he eventually sued the insurance company successfully. The identity of the decapitator was finally established, and Wakley was exonerated. These adventures set the tone for his tumultuous life.

Wakley eventually re-established himself in practice in Norfolk Street, off the Strand. He had become close to William Cobbett, editor of the Weekly Political Register and the Evening Post, whose radical views chimed with his own. Cobbett and his colleagues were highly critical of the political system and Wakley's experience of corruption in London medicine spurred him to seek a platform for his moral outrage, resulting in the establishment of a weekly newspaper devoted to the interests of the medical profession: the Lancet. The first edition, published by A Mead, 201 The Strand, London, appeared on Sunday 5 October 1823, and in the preface to this publication Wakley established himself as arguably the father of evidence-based medicine, writing:

'. . . we conceive, to supply, in the most ample manner, whatever is valuable in these important branches of knowledge; and as the lectures of Sir Astley Cooper, on the theory and practice of Surgery, are probably the best of the kind delivered in Europe, we have commenced our undertaking with the introductory address of that distinguished professor given in the theatre at St Thomas' Hospital on Wednesday evening last. The course will be rendered complete in subsequent numbers.

In addition to Lectures, we propose giving under the head, Medical and Surgical Intelligence, a correct description of all the important Cases that may occur, whether in England or on any part of the civilised continent. ${ }^{2}$

The problem for Wakley was that Cooper had not given permission for these lectures to be published. Indeed, Cooper did not wish to see his lectures published so that he would continue to attract large numbers of fee-paying students to listen to them. Wakley came within an ace of another law suit but the matter was eventually settled between master and pupil, who apparently got on very well together, with Cooper granting permission for publication as long as his name was not attached to the articles. In the next few years, under the constant threat of further law suits for plagiarism, the Lancet prospered, and Wakley continued as editor of the journal until his death, with the Lancet becoming recognized not only as an instrument of medical reform but also the most respected source of current information about medicine.

Wakley's reforming zeal drew him into politics, and he was elected Member of Parliament for Finsbury in 1835, when he took up the case of the Tolpuddle Martyrs. He became a controversial coroner for West Middlesex in 1839. While holding this post he insisted, for the first time, that all members of the Coroner's Jury should be sober while a part of the inquest, and was instrumental in outlawing flogging in the armed services. In 1846 he introduced a Medical Registration Bill, which laid the foundations for the Medical Act of 1858. In 1861, Wakley was found to have tuberculosis and finally travelled to Madeira, where he died of a severe pulmonary haemorrhage on 16 May 1862.

\section{ASTLEY COOPER}

Astley Paston Cooper was born on 23 August 1768 at Brooke Hall, Norfolk, near Norwich, the fourth son of the Reverend Samuel Cooper (Figure 2). Five of his sisters and one brother died from tuberculosis. Cooper grew up, and ran wild, in rural Norfolk. Notorious for practical jokes, on one occasion Cooper, suspecting a publican of keeping a bawdy house, dressed up as a young woman and lured the inn-keeper into a compromising position, at which point Cooper whipped off his disguise, revealing himself as a man. ${ }^{3}$ His interest in surgery was kindled by observing a local surgeon operating for a bladder calculus at the Norfolk and Norwich Hospital. His uncle, William Cooper, was senior surgeon at Guy's Hospital and in 1784 Cooper was articled to him for his medical training, quickly switching allegiance to Henry Cline, a student of John Hunter, at St Thomas' Hospital. Cooper's skills in dissection and his appetite for experimental medicine derived from his contact with these two medical giants. Like Wakley, Cooper's career was launched by marriage to a wealthy retired merchant's daughter, Anne Cock, which provided him with

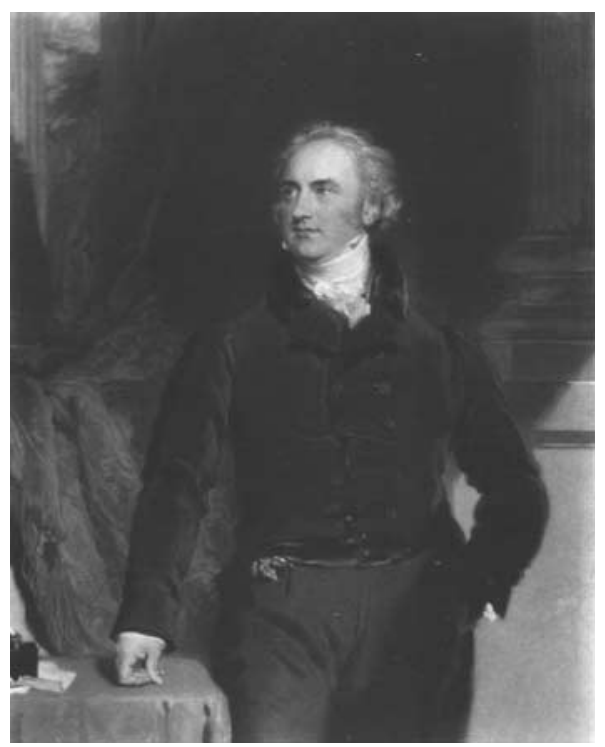

Figure 2 Sir Astley Paston Cooper. 
a dowry of $£ 14,000$. His radical, republican politics, learnt from Cline, were reinforced during a brief visit to revolutionary Paris in June 1792, where the Coopers witnessed at first hand the barbarism of the Terror.

After qualification, Cooper devoted himself to teaching, dissection and experimentation, and over the next three decades his lectures, based on extraordinarily meticulous records of his surgical cases, were the centrepiece of medical education at Guy's, where he became senior surgeon in 1800 .

Cooper was a most attractive individual in terms of personality and appearance, and attracted many wealthy and influential patients, including Lord Liverpool, the Dukes of York and Wellington and also the Prince of Wales who, coming to the throne as George IV, made him a Baronet in 1821, shortly after Cooper successfully removed a painful tumour, probably a sebaceous cyst, from the Royal scalp. Cooper was an amazingly dextrous surgeon, the father of vascular surgery and a pioneer in surgical treatments of hernias and diseases of the breast and thymus gland. His dissection specimens were derived from the activities of the 'resurrection men', the body-snatchers who provided fresh corpses to the teaching hospitals, and also from animals obtained from London Zoo; Cooper famously dissected an entire elephant in the front garden of his house at St Mary Axe in the City of London. Before the passage of the Anatomy Act of 1832, Cooper is recorded as commenting to the House of Commons Select Committee on Anatomy, in 1828, that 'no dead person, however exalted, is safe from the activities of the resurrectionists: the law only enhances the price, and does not prevent the exhumation. ${ }^{4}$

Following his wife's death in 1827, Cooper retired from his London practice and moved to an estate near Hemel Hempstead, where he bred horses. His health deteriorated in 1840 and he died of congestive cardiac failure in Conduit Street, London on 12 February 1841, leaving specific instructions for the conduct of his own post-mortem. His remains lie in the crypt beneath the Chapel at Guy's Hospital.

\section{GEORGE IV}

George IV has been widely regarded as an unsatisfactory monarch (Figure 3). He was born on 12 August 1762 at St James's Palace, taking the titles Duke of Cornwall, Duke of Rothesay and Prince of Wales. A lecher and opium addict, he managed to alienate most of his family. His father, George III, suffering from porphyria, was outraged by the profligate lifestyle that he adopted in Carlton House. His highly dysfunctional relationship with his wife, Caroline of Brunswick, culminated in her exclusion from his eventual coronation in 1820. Court gossip maintained that every time he bedded a woman he cut off a lock of her hair and sealed it in an envelope bearing her name, and that at the time of his death 7000 such envelopes existed.

He was a resolute, if dissolute, aesthete, fascinated by matters of style and taste, and closely linked to the society dandy Beau Brummel and the architect John Nash. As Prince Regent, George was partly responsible for creating the regency style in London domestic architecture, and for the development of Brighton as a seaside spa and the building of the Brighton Pavilion, an exotic seaside palace, designed by Nash in the 'Indian gothic' style, inspired loosely by the Taj Mahal.

George III, whose madness and porphyria are matters of legend, died in 1820, and the Prince Regent ascended the throne as George IV. He was obese, drug-dependent and possibly showed signs of the porphyria that affected his father. His coronation in Westminster Abbey on 19 July 1821 cost almost $£ 1$ million, an unimaginable sum in the early 19th century. George spent much of his reign in splendid isolation at Windsor Castle, but was a persistent meddler in national politics and clashed with the politicians of the day, notably with Lord Liverpool over the Catholic Question.

After his death in 1830, the Times commented:

'There never was an individual less regretted by his fellow creatures than this deceased King. What eye has wept for him? What heart has heaved one throb of unmercenary sorrow? If he ever had a friend-a devoted friend in any rank of life - we protest that the name of him or her never reached us. ${ }^{5}$

George IV's last illness began in the Spring of 1828, when he began to suffer from severe attacks of breathlessness. He could only sleep by propping himself up with

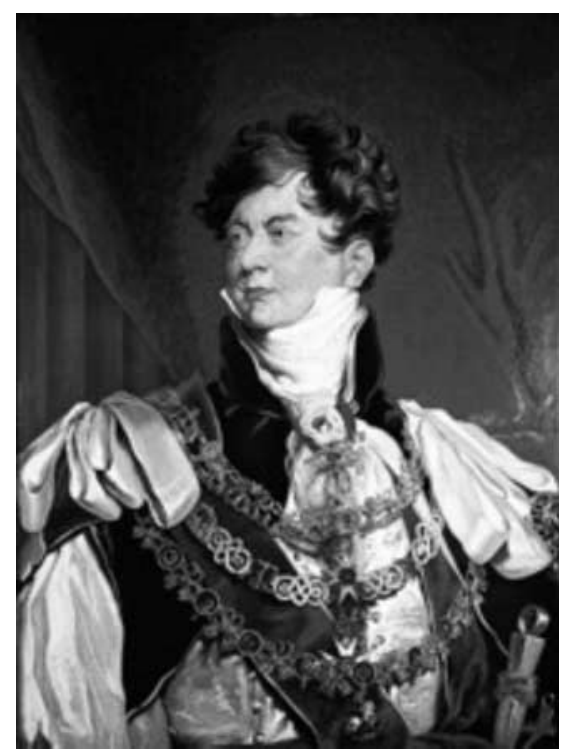

Figure 3 King George IV. 
pillows or sitting in a chair, and he was plagued by bladder pains for which he took increasingly large doses of laudanum. He was, by all accounts, an extremely difficult patient, inordinately anxious and apprehensive about his condition but unwilling to do anything to help himself. His medical attendants were Sir Henry Halford, President of the Royal College of Physicians, and Sir Matthew Tierney and Sir Wathen Waller, both Royal Physicians, as well as sundry other surgeons and an apothecary called O'Reilly whom the King described as 'the damnest liar in the world'. Interestingly, Halford and Tierney, Court Physicians at the time of the death of George III, had previously treated George IV on the day after the death when he developed what sounds very much like broncho-pneumonia. Evidently, he recovered, not entirely thanks to having been bled a total of 150 ounces of blood by Halford and Tierney. Congestive cardiac failure was the cause of his symptoms now, and of his eventual death. Swollen as a result of fluid retention, he was described the Duchess of Gloucester as 'enormous, like a feather bed', and his oedematous legs, 'hard as stone', could only be treated, in the absence of diuretic or other therapy, by puncturing in an attempt to drain away the accumulated fluid. He died, holding Sir Wathen Waller's hand, exclaiming 'My dear boy! This is death!', whereupon he lay back in his chair and expired at 03.15 on 26 June 1830.

\section{THE LANCET EDITORIALS}

The first Lancet article about the health of the King appeared in the third week of May $1830 .{ }^{6}$ All of the bulletins from Windsor Castle issued between 15 April and 20 May were reproduced, and included the following examples:

'Windsor Castle, 19 April 1830. His Majesty continues to suffer occasionally from attacks of embarrassment in his breathing.'

'Windsor Castle, 30 April 1830. The King had several hours of refreshing sleep last night. His Majesty's symptoms are somewhat alleviated.'

'Windsor Castle, 13 May 1830. The King has passed a more comfortable night. The symptoms of His Majesty's complaint, however, do not vary.'

For what purpose, Wakley asked, have these bulletins been issued? They are 'utterly and entirely destitute of information' and there is 'a total silence upon the nature or even of the supposed name of the disease from which our Sovereign has suffered so severe an attack'. If Wakley was critical of the bulletins, he was virtually libellous of their authors:
'Of the incompetency of Sir Henry Halford and Sir Matthew Tierney, we do not speak, for we will not be so uncharitable as to decide upon their medical attainments . . . Sir H Halford is unquestionably a very reputable gentleman, but we have yet to learn that he has found a position among the scientific physicians of Europe. Of Sir M Tierney we know nothing: he may have contributed to the stock of medical knowledge; he may have been successful in the career of private practice; but upon each of these points we are equally in the dark. ${ }^{6}$

Wakley had discovered that the King's oedematous legs had been punctured to relieve the fluids, and was critical that this potentially dangerous (because of the risk of sepsis) surgical operation was performed without the name of the surgeon being stated:

'The secrecy is deep, but what are the motives? The history of the magical tactics of the Great Magician may one day furnish an explanation. The extraordinary benefit, both medical and surgical, rendered to the late Duke of York by His Majesty's Sergeant-Surgeon, Sir Astley Cooper, is well known to the members of the medical profession and even to a large portion of the public. Yet "the Conjuror" on this occasion directed his wand to another quarter, and summoned to his aid a more convenient spirit; one that could be concealed or exhibited . . . ${ }^{6}$

The implications were clear. The power behind the throne had chosen to exclude the leading physician of the day and to have the King treated by senior medical political figures of dubious competence.

The next week saw more bland Palace bulletins and more invective from Wakley:

'What an extraordinary jumble... The public and the profession are as much in the dark now relative to the malady with which it has pleased Providence to afflict His Majesty as they were before any of the things called "bulletins" were issued... The enchanter of the Palace is apparently endowed with more than human daring, or he would not have resolved, without a previous consultation with the first surgeons of the Kingdom, upon the hazardous and frequently fatal operation of "puncturing". '7

On 5 June Wakley continued his criticisms of the bulletins and the King's medical attendants, turning his attention to Sir Wathen Waller, who he described as 'an elderly gentleman, formerly an oculist ... who acquired some notoriety by the operation of couching, which he performed upon Lady Howe. ${ }^{8}$ Wakley once again called for Astley Cooper's involvement in the King's care, referring to:

'The signal service . . . which it is known the worthy Baronet rendered to the late lamented Duke of York, whilst he was suffering from dropsy, and subsequent mortification at the 
extremeties . . . Sir Astley had prescribed the blue pill, squill root and digitalis. We have ourselves, on several occasions, seen the administration of these medicines in dropsical affections followed by most unexpected and permanent benefit. As we have received multitudes of enquiries for Sir Astley Cooper's remedies in dropsical complaints we shall here present the public with the worthy Baronet's formula in his own words, given in a lecture delivered at St Thomas' Hospital . . . '

The article concluded with the full recipe for Cooper's miraculous remedy. ${ }^{8}$

By 12 June Wakley's invective, often using ten words where one would have done, was becoming repetitive, if not frankly tedious. ${ }^{9}$ The vacuous Bulletins continued, but three new points did emerge. The first was that the Palace claimed that the reason that the bulletins were so devoid of medical information was that they were read by the King before publication. The second was that Matthew Tierney was asked to watch over the King at night because of the 'indisposition' of Sir William Knighton, the King's closest advisor (of whom more later). The third was that following the publication of Cooper's prescription for the treatment of congestive cardiac failure, an article was published in the Morning Herald suggesting that Cooper's treatment of the Duke of York was not only inappropriate for a surgeon but had led to gangrene of his oedematous legs.

The first paragraph of Wakley's next editorial, which appeared on 19 June, was a distinct hostage to fortune:

'The feelings of disgust, and almost indignation, with which we have been in the habit of reading these documents are, in some measure, softened, if not dissipated, by the knowledge of the fact that His Majesty's sufferings are considerably mitigated. ${ }^{\prime 10}$

Nonetheless, Wakley's tireless criticism of the content of the bulletins, the quality of the King's medical care and of the workings of secret influences behind the throne continued unabated. The editorial ended on a relatively upbeat note:

'During his recent very severe and alarming attack, Mr Nussey, the apothecary of Cleveland Row was sent for, and to the diuretics and expectorants prescribed by this gentleman is attributed the present alleviation of His Majesty's sufferings. From certain indications, it appears probable that Sir Astley Cooper may even yet be consulted.' 10

Rather ironically, the final editorial on this extraordinary episode was published on the day the King died, 26 June, but the Lancet had gone to press before news of the death could have influenced its content. Wakley remained tirelessly critical and was also candid enough to publish an
Nussey the previous week, which reflected the continuing tensions between apothecaries, physicians and surgeons in the early 19th century:

'So far as relates to the circumstance of Mr Nussey having been down to take his turn of attendance on His Majesty is perfectly true, but as regards the statement of "the diuretics and expectorants prescribed by this gentleman" the story is wholly unfounded. Every body knows that in cases of such high national import the task of prescribing does not usually devolve upon the apothecary, however great a favourite he may have the honour to be, but is commonly entrusted to and exercised by the physician alone.' 11

The prognosis implied in the last paragraph of the editorial, describing the King as being in a 'state of emaciation', proved all too accurate.

The final Lancet editorial, dated 3 July, ${ }^{12}$ looked back over the last few weeks, and begins by re-printing all the bulletins issued from Windsor Castle between 15 April and 26 June, largely in support of Wakley's charge that 'the deception practised upon the public has been of so scandalous a nature, and the bulletins issued by the medical attendants have been so justly and severely reprobated, that we think it right to collect the whole of these documents and place them in one view, before the eyes of this insulted community.' ${ }^{12}$

This final editorial - highly political, highly critical —at last begins to clarify Wakley's views about the 'magician' and his influence at Palace in this key section:

'Some allowance may, with justice, be made for the medical attendants, acting, as they did, under the immediate direction of Sir William Knighton, whose conduct was well calculated to chill their ardour, as he does not scruple to hold himself up as one of the first doctors of the age. The late King took no medicines for several years past, without the approbation of this obstetric doctor; and no medical practitioner was ever admitted into the Royal bedchamber, without his sanction and especial permission. In fact the same rigorous espionage which he exercised over the footmen and chambermaids, was visited upon the Royal physicians; but Sir W Knighton, to the great joy, we believe of the inmates of the Palace, no longer holds the office of Privy Purse. His dismissal on the immediate demise of the Crown, speaks volumes for the character of his long, flourishing, "invisible" tactics.' 12

Wakley finally got his way. 'Sir Astley Cooper was summoned by the Lord Chamberlain to conduct the dissection. The worthy Baronet has evidently written the account in no unfriendly spirit towards to His Majesty's medical attendants, whose condemnation, nevertheless, bursts forth in every line.' Cooper's notes on the Royal post-mortem record finding two pints of fluid in the right 
thoracic cavity and 3.75 pints in the left; there was left ventricular dilatation and the cause of the King's heart failure was found to be calcific aortic stenosis. The immediate cause of death was the rupture of a vessel in the stomach, which was full of blood. ${ }^{13}$

In a final fascinating twist to this unhappy example of terminal care, at a meeting of the Royal College of Physicians a few months later Sir Henry Halford gave a most candid Presidential address on the subject of truth-telling in medicine. He said that his practice had previously been to withhold severe and potentially terminal diagnoses from patients lest they should 'alarm the sufferer and aggravate his disorder by exhibiting to his view the awful image of approaching death.' Halford had applied this approach to the care of the late King until His Majesty himself desired that he might be informed of the cause of the sufferings he endured. In a remarkably affecting, and far-sighted, passage, Halford went on to write:

'The King, upon the danger of the disorder, immediately prepared himself for death. Having set his house in order he received the sacrament and, from the administration of that holy office, declared that he had received the greatest comfort and consolation. By pursuing this course His Majesty's cheerfulness was preserved, and he died without being disturbed by the prospect of approaching dissolution.' ${ }^{14}$

\section{SIR WILLIAM KNIGHTON AND LADY CONYNGHAM}

Two more characters now enter the drama, Sir William Knighton (Figure 4) and the notorious Lady Conyngham (Figure 5). It looks fairly clear from Wakley's last editorial that Sir William Knighton was, in fact, the 'magician' and 'conjuror' pulling the strings at Court. But who was he, and what did he have to gain by excluding Astley Cooper from looking after the King?

Knighton came from humble Devonian origins. He originally studied medicine in Tavistock, spent some time at Guy's and became an assistant surgeon at the Royal Naval Hospital in Plymouth. Marrying a captain's daughter, he moved to London and eventually became a fashionable accoucheur in Hanover Square. Knighton's first contact with the Prince of Wales, later George IV, came after Knighton accompanied Lord Wellesley and one of his mistresses, Moll Raffles, a patient of Knighton's, to the Spanish Embassy in 1809. They apparently got on like a house on fire and Knighton was rapidly appointed one of the Prince's physicians-in-ordinary. Within two years he had been created a Baronet. He went on to become extraordinarily close to the King in a relationship (described by Christopher Hibbert in his superb biography of George IV) ${ }^{5}$ which had a somewhat homoerotic flavour, with the King frequently demanding the urgent presence of his 'dear,

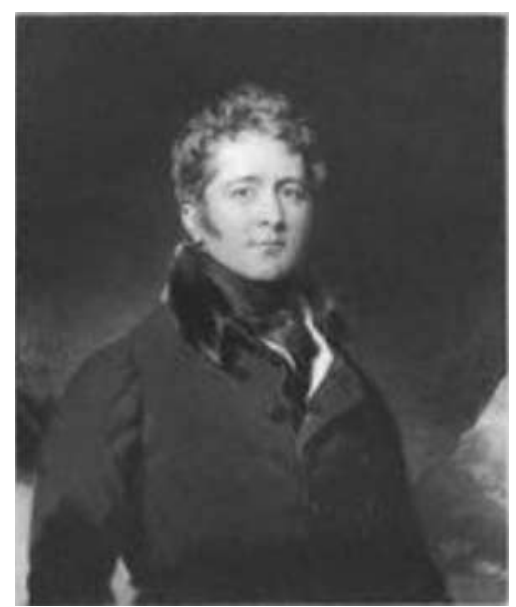

Figure 4 Sir William Knighton.

very dear friend, his very best friend', heaping extravagant praise and 'incoherent hyperbole' 15 on his pedestrian verse, and Knighton reciprocating with 'if you knew, Sir, what I really and sincerely felt, your Majesty would scarcely believe the extent of my anxiety and misery respecting you. Burn this if you please.' 16

Knighton's power at Court was confirmed when, after rescuing the King from near-bankruptcy, he was made Keeper of the Privy Purse, and remained close to the King and was influential in his thinking and the affairs of the Court until his death.

Finally, Lady Elizabeth Conyngham. Hibbert describes her as a 'fat, kindly, religious, rich and rapacious woman', a fading beauty at the time that the King took her as one of his many mistresses and fell in love with her. ${ }^{17}$ George was besotted with Lady Conyngham and their relationship was

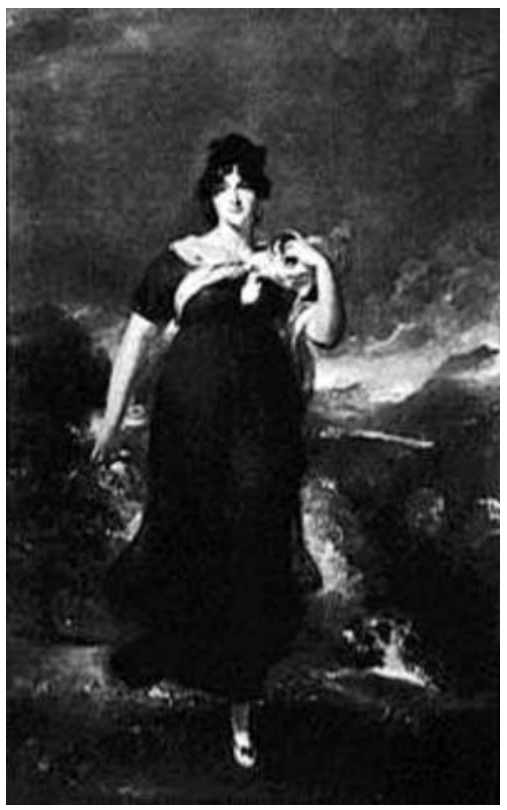

Figure 5 Lady Elizabeth Conyngham. 
well known both to the public and to the cuckolded Lord Conyngham. George seemed to take particular delight in Lady C's maternal qualities and in her children and the family life which he never enjoyed with his own wife, Caroline of Brunswick. George clashed with his ministers and with Lord Liverpool over his attempts to install various Conynghams in key posts in the Church and at Court, and also fell out with the Duke of Wellington over his relationship with them. Indeed, when the King formally declared his wishes (witnessed by Halford, Tierney and Knighton), to leave everything to Lady Conyngham, Wellington came down to Windsor and threatened Lady Conyngham if she took advantage of it. He told her among other 'gentleman-like' speeches that she was like Madame du Barri, and that Madame du B's conduct brought about the French Revolution! ${ }^{18}$ Lady Conyngham had much to gain from the death of George IV, and indeed, much did she gain, apparently having taken whole wagon loads of treasure to her country house in Kent. According to one contemporary account, Lady Conyngham 'first packed, then prayed, then packed again. ${ }^{1} 19$

\section{WHY WAS COOPER KEPT AWAY?}

If Wakley is correct, and Knighton was, indeed, some kind of magician behind the throne, what were his possible motives in excluding Cooper from Court? He certainly didn't gain anything by George's death, and indeed lost his job immediately afterwards. There is no evidence that Lady Conyngham had a particular hold over him and, in any case, she had no particular motive for keeping Cooper away herself. Cooper's earlier ministrations had helped the Duke of York temporarily, but he eventually died of congestive cardiac failure, and there was no way that Cooper was going to save the life of the King. George was doomed, and keeping Cooper away so that he died more quickly must be an implausible motive for Knighton's actions.

Knighton, according to Wakley, had an inappropriately high opinion of himself as a doctor. Cooper, however, was by public acclaim the pre-eminent clinician of his day, and his arrival at Court would undoubtedly have threatened not only Knighton but Halford, Tierney and Waller, who Wakley portrays as medical buffoons. Knighton had signed the letter appointing Cooper his Majesty's SergeantSurgeon in 1820, but perhaps it was not only the conjuror but also the court jesters Halford and Tierney who, fearing for their reputations, wished exclude their brilliant rival. And is it remotely possible that Knighton saw Cooper as a rival for the King's affections, which had been bestowed so lavishly on him? Little is known about any contact that Cooper and Knighton might have had at Guy's, or whether any other professional interactions had led to animosity or been at Guy's, but Knighton was in practice by the time that Wakley was a medical student. Although relationships with Cooper, and the libel action with his cousin Bransby Cooper, figure prominently in Squire Sprigge's biography of Wakley, there is absolutely no reference to George IV or to Sir Matthew Tierney, and Sir Henry Halford appears only fleetingly. And what of Cooper's relationship with the King? We know that he was held in high regard by the monarch following the scalp operation, and Bransby Cooper's biography of Astley Cooper ${ }^{20}$ contains several pages of appreciative notes about the King written by Cooper, who was complimentary about his interests in science and knowledge of medicine - no traces of an animosity which might have caused George to ban Cooper from his sick room.

So the reasons for the exclusion of Astley Cooper from the medical care of King George IV must, for the time being, remain uncertain, as too must those for the intensity of Thomas Wakley's outrage at his exclusion. This catalogue of medical intrigue and the accompanying example of radical medical journalism remain subjects for further research.

Competing interests None declared.

Funding None.

Guarantor RJ is the guarantor for this paper.

Contributorship RJ was solely responsible for wring this paper.

\section{REFERENCES}

1 Sprigg S. The Life and Times of Thomas Wakley. London: Longman Green \& Co, 1899

2 Anonymous. Preface to The Lancet. Lancet 1823;1:1-2

3 Cooper B. The Life of Sir Astley Cooper Bart. London: John W Parker, 1843:53-4

4 Ibid, 407

5 Hibbert C. George IV. London: Penguin Books, 1976:782-3

6 Anonymous. The King. Lancet 1830;14:295-7

7 Anonymous. The King. Lancet 1830;14:340-3

8 Anonymous. Discussion: The King. Lancet 1830;14:380-91

9 Anonymous. Discussion: The King. Lancet 1830;14:430-2

10 Anonymous. Discussion: The King. Lancet 1830;14:457-61

11 Anonymous. Discussion: The King. Lancet 1830;14:497-502

12 Anonymous. Discussion: The King. Lancet 1830;14:546-54

13 Anonymous. Discussion: Dissection of His Late Majesty. Lancet 1830; 14:578-82

14 Anonymous. Royal College of Physicians: The Late King. Lancet 1830

15 Hibbert C. George IV. London: Penguin Books, 1976:641

16 Ibid, 642

17 Ibid, 627

18 Ibid, 767

19 Leslie S. George the Fourth. Boston: Little, Brown \& Co, 1926:165-6

20 Ibid, 346-54 